DOI https://doi.org/10.30525/978-9934-26-117-6-15

\title{
ФУНКЦІОНУВАННЯ ЛЬВІВСЬКОГО ОПЕРНОГО ТЕАТРУ В УМОВАХ НІМЕЦЬКОЇ ОКУПАЦІЇ
}

\author{
Фішер T. П. \\ пошуковувач кафедри історії музики \\ теоретико-композиторського факультету \\ Львівська національна музична академія імені М. В. Лисенка \\ м. Львів, Україна
}

Середина XX століття могла б стати розквітом в культурному житті Львова та Східної Галичини в цілому. Здорова творча конкуренція між чотирма вищими навчальними закладами (Консерваторією Галицького музичного товариства, приватним закладом А. Нєментовської Консерваторією ім. К. Шимановського, Вищим музичним інститутом ім. М. Лисенка та Інститутом музикології Університету ім. Я. Казимира [2]) стала логічним завершенням історії спільного існування культурних громад у Львові (йдеться про українську, польську, єврейську та чеську етнічно-культурні громади) тривалістю в кілька століть. Останнє передвоєнне десятиліття було насиченим і багатим на культурні події, учасниками яких були Симфонічний оркестр Львівської філармонії, Оперна та балетна трупи Великого міського театру, Драматичний театр, численні виконавці-солісти (і представники локальної виконавської школи, так і знані виконавці-гастролери з Свропи). Особливе становище в цьому розмаїтті мали українські професійні музиканти: витіснені на другорядні позиції в умовах бездержавності, митці, намагалися досягнути рівнозначного європейському рівня професіоналізму та забезпечити українцям Галичини гідний мистецький побут в царині і камерно-інструментальної, і симфонічної, і хорової музики а також музичного театру. До вибуху Другої світової війни діячам вдалося розв'язати (чи принаймні розпочати процес вирішення) низку проблем, що унеможливлювали чи гальмували розвиток української культури на бажаному рівні. Питання освіти (організація навчальних закладів всіх рівнів, кваліфікаційних курсів для широкої аудиторії, створення підручників та педагогічного репертуару, налагодження нотодрукування), аматорського виконавства, налагодження концертного життя, забезпечення якісного музичного контенту в ефірі львівського радіо, розвиток українського музикознавства - ось коло 
завдань, що було в компетенції членів Музичного товариства імені Миколи Лисенка, СУПроМу та інших діячів.

Проте початок Другої світової війни, дві окупації (радянська та німецька) скоригували перспективні плани розвитку та змусили українську мистецьку еліту пристосовуватися до нових реалій. Частиною порядку денного були концерти симфонічної музики, масштабні вокально-інструментальні чи хорові події та оперні постановки, а відтак і автори та очільники цих проектів: оперні та симфонічні диригенти, що волею обставин опинилися в окупованому німцями Львові.

Однією 3 невирішених проблем української культурної громади була відсутність постійного драматичного та оперного театрів для українських труп. Адже Український драматичний театр орендував різні (часто зовсім не придатні для постановок) приміщення, ховаючись від утисків польської влади. Щодо Львівської опери, то до 1939 року основу виконавського складу становили польські музиканти. 3 українців до співпраці залучали лише тих, хто відточував майстерність та здобув визнання поза межами батьківщини здебільшого в якості запрошених виконавців (Модеста Менцинського, Олександра Мишугу, Філомену Лопатинську та інших). 3 приходом радянських військ і приєднанням західно-українських земель ситуація змінилася: в репертуарі 3'явилися опери та оперети російських та українських композиторів, польські музиканти стали меншістю в виконавському колективі, що було наслідком жорстоких репресій. Чергова реформа діяльності театру відбулася в 1941 році.

На початку становлення окупаційного режиму українська трупа зайняла Міський театр та відновила постановки. Проте через пів року, коли директиви нового правління набули чинності, - Львівський театр одержав статус репрезентативного та повне фінансування від нової влади. Місто стало рекреаційною зоною для німецьких військових, що в ході ротації прибували до дистрикту 3 лінії гарячого фронту на лікування чи зупинялися на відпочинок перед тим, як рушити на захід, а театр - центром, що мав задовільнити культурні запити різноманітних груп окупантів [1] від високоосвіченої військової старшини до рядових солдат. Нова влада залишила українське керівництво (директора Андрія Петренка, заступників - Володимира Блавацького, Петра Сороку), але впливала на підбір трупи та формування репертуару через цензуру. Окрім того, реорганізували структуру театру: відтепер під куполом ЛОТу існували чотири різні інституції: Театр опери, Театр балету, Театр оперети та Німецький театр, а також відбувалися вистави Українського драматичного театру [4]. Основу репертуару складали 
кращі зразки італійської, німецької, французької оперної літератури романтичного періоду. Вистави відбувалися у двомовному режимі : українською та німецькою. вистави для німців відбувалися у зручніший час і тричі на тиждень. Низка заходів проходила під знаком лише для німців. До участі в знакових подіях чи виставах запрошували солістів із Німеччини.

Творчий колектив театру налічував близько 400 осіб, серед яких : оркестр у складі 50 осіб, солісти та актори (бл. 50 осіб), хор у складі 40 осіб та 35 артистів балетної трупи. Відносна безпека (віддаленість від лінії фронту) можливість врятуватися від радянських репресій, зробили Львів містом, де зосередилися не лише виконавці з Галичини, а й 3 інших регіонів України.

В період з 1941 по 1944 під куполом Опери поставили понад 60 різних творів, значно розширивши попередній репертуар (за півтори року від липня 1941 р. до грудня 1942 р. відбулось 424 вистави [3], частина поставок відбувалась у двомовному режимі). За диригентським пультом в ці роки працювали : музичний керівник Лев Туркевич, диригенти Ярослав Барнич, Нестор Горницький, хормейстер і диригент Ярослав Вощак, М.Гончаров, а також два диригенти «тільки для німецької публіки» - Фріц Вайндліх та Альфред Копп. Серед добре знаних виконавців в цей час співали : Є.Поспієва, Я.Оконська, М.Сабат-Свірська, І.Маланюк, С.Гаврищук, І.Туркевич-Мартинець, Л.Німців, І.Войцехівська, Н.Шевченко, В.Тисяк, Ю.Лаврівський, Л.Рейнарович, Б.Паздрій, М.Старицький, Д.Йоха, І.Рубчак. Вдалим поповненням високопрофесійної трупи стали музиканти, що емігрували із центральних та східних областей України до Галичини [3].

\section{Література:}

1. Антонюк Н. Українське життя в «Генеральній Губернії» (19391944): За матеріалами періодичної преси. - Львів, 1998. - С. 27.

2. Львівське державне музичне училище ім. С. Людкевича. Сторінки історії / Ред.-упор. Н. Пузанкова. - Львів: ТеРус, 2009 - C. 3-10.

3. Львівські вісті - № 179 (599), вівторок 10 серпня 1943 p.

4. Офіциський В. Діяльність «Об'єднання праці українського студентства» за матеріалами журналу «Студентський прапор» (19431944). Українські землі в роки Другої світової війни: Наук.-метод. зб. матер. конферениї / Упоряд. В. Мельник і Р. Офіцинський. - Ужгород: Патент, 1998. - С. 141-161. 